\title{
Business Systems and Corporate Governance
}

\author{
Pedersen, Torben; Thomsen, Steen
}

Document Version

Final published version

\section{Publication date: \\ 1999 \\ License \\ CC BY-NC-ND}

Citation for published version (APA):

Pedersen, T., \& Thomsen, S. (1999). Business Systems and Corporate Governance. Department of International Economics and Management, Copenhagen Business School. Working Paper / Department of International Economics and Management, Copenhagen Business School No. 1-1999

Link to publication in CBS Research Portal

\section{General rights}

Copyright and moral rights for the publications made accessible in the public portal are retained by the authors and/or other copyright owners and it is a condition of accessing publications that users recognise and abide by the legal requirements associated with these rights.

\section{Take down policy}

If you believe that this document breaches copyright please contact us (research.lib@cbs.dk) providing details, and we will remove access to the work immediately and investigate your claim. 
February 17, 1999

\section{Business Systems and Corporate Governance}

Torben Pedersen, Associate Professor, Department of International Economics and Management, Copenhagen Business School, Nansensgade 19.7, 1366 Copenhagen K. Denmark. Email tp.int@cbs.dk.

Steen Thomsen, Professor, Department of International Business, The Aarhus School of Business, Fuglesangs Alle’' 4, 8210 Aarhus V. Denmark. E-mail stt@hha.dk. Aarhus School of Business

Abstract: The paper tests the applicability of Whitley' s business systems framework to the study of international differences in corporate ownership structure. In support of Whitley's framework we document the existence of large differences among the largest companies in 12 European nations. Furthermore we find that these differences can be partly attributed to the institutional determinants stressed by Whitley: structure of the financial system, government regulation and labour relations. However, we also find evidence of microeconomic effects attributable to firm size and industry structure which cut across national borders and which influence cross country variations in ownership structure. We conclude that ownership structures are influenced by both economic and system effects. 


\section{Introduction}

Since the beginning of the 1990s a large number of economic and legal studies have documented the existence of significant international variations in corporate governance (Franks and Mayer 1990, 1995, Roe 1991 and 1994a, Prowse 1995, Moerland 1995, Shleifer and Vishny 1997, Pedersen and Thomsen 1997, Laporta et al. 1997, 1998a, 1998b, as well as more descriptive work by Buxbaum and Hopt 1994, Charkham 1994, Porter 1992, Prentice and Holland 1993 and others). But apart from the investor protection explanation launched by Laporta, Silvanes, Shleifer and Vishny (1998) - which regards ownership diversification as a function of legal protection of small investors - little systematic research has been done on the determinants of international differences in corporate governance. Instead the existence of international differences as such has been advanced as an argument against economic ownership theory, c.f. Roe (1994a): " ..... the differences suggest that differing histories, cultures and paths of economic development better explain the differing structures than economic theory alone." (p. 28)

This paper turns to sociology - to the business systems analysis of Richard Whitley (1994,a, 1994b, Whitley and Kristensen 1996) - for a deeper understanding of the origins of corporate governance systems. By testing the business systems framework the paper aims to contribute to the ongoing dialogue between economics and sociology (in the spirit of Foss 1997).

The paper is structured as follows. Section 2 discusses Whitley's framework and its application to the study of international corporate governance compared to other contributions. Section 3 presents the data. Section 4 provides an overall empirical test of the model which 
regards corporate ownership structure as determined by system effects (nationality) and economics (size and industry effects). Section 5 provides a closer examination of the nation effect and its institutional origins. Section 6 concludes.

\section{Business systems and corporate governance}

This section discusses Whitley's business system concept and its application to international corporate governance. The reference text is Whitley (1992).

According to Whitley (1992 p. 4) business systems .. " are particular ways of organizing, controlling and directing enterprises" (p. 7) or "particular arrangements of hierarchy-market relations which become institutionalized and relatively successful in particular contexts", which is almost exactly equivalent to some of the broader definitions of corporate governance (Charkham 1994, Williamson 1996). These “distinctive ways of organising economic activities become established and effective because of major differences in key social institutions, such as the state, the financial system and the education and training system" ( $p$. 13) including labour market organization (p. 16).. as well as the indirect influence of "more general and diffuse attitudes and beliefs about work, material values and authority relations" (p. 16), "family and kinship relations, identities and authority structures". Business systems consist of differences in "First, the nature of the firm. Second, the connections that firms develop with each other .. Third, how activities and skills are coordinated within firms.." (p. 18). While business systems often coincide with national economies, it is recognized that "As well as distinct systems within nation states, there are of course substantial differences 
between firm structures and connections across industries”. Furthermore, nation states need not have equally homogeneous business systems. It is stressed that " in societies where major social institutions are highly differentiated and have been established for some time since industrialization took place - such as Britain and the USA - business systems are not as internally homogenous and mutually distinct as those in recently industrialised societies which are less institutionally pluralistic” (p. 17). The more homogeneous, less pluralistic systems develop particularly "distinctive managerial rationalities and practices”. The social institutions which emerge from this do not obstruct the market mechanism, but provide institutional foundations for efficiency. They "are key phenomena in the constitution of different competitive orders and should not be counterposed to market efficiency".

The key elements in this framework seem to be as follows. 1) National business systems differ in particular with respect to corporate governance. 2) The differences stem from differences in key social institutions (government regulation, the financial system, labour market institutions, culture). 3) In contrast, business systems and governance are presumably less influenced by microeconomic factors like transaction costs. 4) The more differentiated the key social institutions are, the more differentiated the nature of the business system, and differentiation may be expected to increase over time as a function of economic development. In particular greater differentiation is expected in the Anglo-American business system. 5) Individual business systems develop distinctive, viable business philosophies and ways of doing business.

In principle the elements in this framework are all testable In this paper we test the business system concept by applying it to explain variations in corporate ownership (a key determinant of corporate governance) among the 100 largest companies in each of 12 European nations. 
Specifically, we test the 4 hypotheses listed below.

Hypothesis 1. Large international/system variations in corporate governance are to be expected.

Hypothesis 2. In contrast, economic efficiency as expressed in general (cross-country) economic factors, is expected to have little impact on corporate governance because economic efficiency is socially constructed and the economic rules of the game will differ from system to system.

Hypothesis 3. The nation/system differences will be a function of differences in key institutions: government regulation, the nature of the financial system and labour relations.

Hypothesis 4. Highly developed systems (wealthy, early industrializers) - like the US/UK - will have less uniform corporate governance modes than less developed systems (late industrializers). 
These hypotheses are explained in the rest of this section and tested in the rest of the paper. Out viewpoint is that an assessment of the business systems framework requires the discipline of comparison with alternative theories and hypotheses.

Hypothesis 1. Large international variations in corporate governance are to be expected. The existence of such differences is a precondition for the relevance of Whitley's argument. A lack of significant international differences would refute the core of the business system framework. Although Whitley (1994b) has constructed system categories we have chosen to focus on the national level because of the subjectivity bias inherent in classifying nations by system.

A theoretical alternative to the business systems view is referred to by Whitley as "economic rationalism", under which heading he subsumes both neoclassical and transaction cost economics and other approaches. An extensive economic literature now exists on corporate ownership and governance including important contributions by Coase (1937), Demsetz (1983), Jensen and Meckling (1976), Williamson (1975, 1985, 1996), Hart (1995), Hansmann (1988, 1996), Fama and Jensen (1983), Putterman (1993), Laffont and Tirole (1993), Shleifer and Vishny (1997). In economic ownership theory, corporate governance is seen as a cost efficient response to coordination and incentive problems. For example, ownership concentration is predicted to decrease with firm size, vertical integration is seen as a solution to hold up problems under conditions of asset specificity, and government ownership is 
regarded as a more or less efficient response to externalities. Often, the theory has abstracted from system effects except for assuming that transactions take place in a in a free enterprise economy ("In the beginning there were markets", Williamson 1975). But this restriction is arguably a consequence of a parsimonious the analytical approach rather than a result of inherent inability to deal with such effects, which have in fact been analysed by Williamson (1993, 1996) and North (1990) among others. And large sub fields within economics do analyse the causes and effects of various kinds of intervention in the market place (for example the effect of taxation, market size, dual class shares, etc.), comparative economic systems and the like. Therefore, the existence of nation effects does not in itself demonstrate the irrelevance of economic factors such as differences in market size, industry structure etc..

Hypothesis 2. In contrast, economic efficiency as expressed in general (cross-country) economic factors are expected to have little impact on corporate governance because economic efficiency is socially constructed and the economic rules of the game will differ from system to system. Whitley explicitly recognizes that business systems can be shaped by industry effects (Whitley 1992 p. 15), i.e. that individual industries can develop their distinct "business recipes", but maintains that economic factors "will not generate highly dissimilar business systems". In this paper we borrow an analytical approach from industrial economics (Scherer and Ross 1989) to test this hypothesis: to the extent that corporate governance structure in given industries tend to be similar across national borders, this can in fact be regarded as evidence of underlying economic effects which are robust enough to cut across systems. In other words we test whether there are differences in ownership structure by 
industry when controlling for nation effects. While the business system framework is broad enough to encompass significant industry variation within any single system it cannot explain why this variation should be correlated across national boundaries.

Hypothesis 3. The nation/system differences will be a function of differences in key institutions: government regulation, the nature of the financial system and labour relations.. System differences caused by regulation and alternative financial institutions also figure prominently in the economic literature. As mentioned, empirical evidence that ownership structures are influenced by the legal system forms the basis for Roe' s "political theory" of ownership (Roe 1991, 1994). Specifically, Roe $(1991,1994)$ argues that the regulation of financial institutions determines whether countries adopt (US-style) market-based systems with highly dispersed ownership or (German-style) bank based systems with more concentrated ownership. But although he hints at a political / public choice explanation Roe does not explicitly address the question of why politicians in different nations regulate their financial systems the way they do.

We have previously argued (Pedersen and Thomsen 1997) that further progress is possible by drawing on the new institutional economics, especially North's work on institutions and efficiency (North 1990) and Williamson's integration of system parameters into transaction cost analysis (Williamson 1991, 1993). Douglas North (1990) highlights the importance of lock-in effects occurring when regulation allows particular organizational structures to develop which then reinforce the pattern of regulation. This leads to path dependency because once a given ownership structure is in existence it will tend to reinforce itself by developing a network of complementary institutions. For example the Anglo-American market-based model has 
created a finely tuned network of investment analysts, stockbrokers and institutional investors which at the same time improve the efficiency of the system and lobby for its continued existence and expansion. No comparable network is developed in markets with a high degree of financial intermediation but here banks or other organizations may assume new functions and a more powerful political role. The implication is that corporate governance systems are essentially historically determined, for example (as argued by Whitley) by the historical pattern of industrialization.

The historical view is essentially a theory of lock-in and path dependency but is less helpful in analysing (or guiding) institutional change. In caricature, it simply implies that "everything is the way it is because it was the way it was". To move beyond this half-tautological level it is necessary to analyse the effects of particular institutions, changes in which can modify the workings of the corporate governance system. Although Whitley (1994) emphasizes continuity and argues that large scale systems change is improbable, substantial changes have taken place in American corporate governance since the days of J. P. Morgan, in Japanese corporate governance following the dismantling of the family based Zaibatsus for more loosely knit Keiretsus, or in German corporate governance since the days of Walter Rathenau and the dissolution of I.G. Farben. Here, Whitley's references to the role of the state, the financial system and labour organization provide a more specific, although still quite broad, analytical focus.

One way to make this framework operational is to focus on government regulation which interferes directly in corporate governance (e.g. legal rules restricting the ownership rights of financial institutions or foreign ownership, taxation of personal/family ownership vs. 
Institutional investors, regulation of board size, composition and responsibility etc.). Another way is to focus directly on complementary financial institutions, e.g. the size and liquidity of the national stock market vis-a-vis the banking system. These measures are shown to have some explanatory power in Pedersen and Thomsen (1997). A third more specific causal mechanism from institutions to corporate governance is proposed by La Porta et al. (1998a) who argue that legal systems differ in terms of investor protection and that low rates of investor protection lead to high rates of ownership concentration as an alternative means to discipline managers.

The observation that large changes as mentioned above have taken place historically also tend to discredit casual references to the cultural origins of corporate governance as in the above quotation by Roe (1994a). The same objections apply to the argument proposed by La Porta et al. (1997) with a reference to Fukuyama (1995) that low-trust cultures tend to promote family ownership whereas high-trust cultures can sustain large public corporations with highly dispersed ownership because they enable a certain level of trust even among anonymous individuals and trading partners. While culture is difficult to define, there is virtual agreement in the literature (e.g. Hofstede 1980) that cultures change very slowly, if at all, which seems inconsistent with the magnitude of these changes. Obviously, this does not preclude that culture plays an important role as a background for changes in formal institutions as emphasized by Whitley, but it means that cultural variables must be supplemented by reference to other causal mechanisms, for example by reference to changes in the above mentioned formal institutions: "Because business systems are interdependent with dominant institutions, major changes in their characteristics depend on related changes in associated institutions" (Whitley 1994). 
Hypothesis 4. Highly developed systems (wealthy, early industrializers) - like the US/UK - will have less uniform corporate governance modes than less developed systems (late

industrializers). The hypothesis of greater differentiation in more "advanced" economies (like the US/UK) than in newly industrialized or continental nations can be tested by examining to what extent the corporate governance structures of UK firms are more or less similar than the governance structures of firms in the "less advanced" continental nations.

\section{The data}

Corporate governance - the mechanisms by which companies are controlled and directed - is a complex subject which is influenced by owner-manager relations, stakeholder relations, board structures and practices, management compensation, capital structure, company law and other variables. In this as well as in previous papers (Pedersen and Thomsen 1995, 1997, 1998), we have chosen to focus on ownership structure, not because other factors are unimportant, but because corporate ownership is a measurable variable which plays an important role in economics as well as in management studies. We regard corporate ownership as a structural determinant of corporate governance. and explore a structure-conduct-performance paradigm according to which a set of basic conditions (system, industry etc.) determine ownership structure which then jointly influence company behaviour and ultimately performance. 
Although many aspects of corporate governance are directly determined by nation/system effects we need an independent measure of corporate governance in order to assess the magnitude and significance of the system effects. And our emphasis on the importance of ownership structure appears to be compatible with Whitley's thinking : "Since market economies are defined largely in terms of private ownership and control of economic resources and activities, the organization of property rights and the relations between owners and controllers of resources are key differentiating features of these economies" (1992, p. 157).

We focus on the largest corporations in individual countries, partly because we expect to find more varied governance structures among these companies. To some extent this may tend to overstate the impact of nation and systems effects since private ownership (personal/ family majority ownership) is characteristic for smaller companies in all market economies.

Research in European ownership structures has previously been inhibited by a lack of publicly available information. Moreover, ownership arrangements are often complex and so is the legal/institutional environments in which they are embedded. However, the situation has improved in recent years, and a number of databases (Amadeus, World Scope, Who own Whom, Directory of Multinationals) now contain ownership information on European companies. Although the information available is still not comparable to what is obtainable on US companies, the coverage of large ownership stakes has improved in recent years, and since ownership structures tend to be more concentrated in Europe, large share holdings are a better discriminant there than in the US. We use this fact to construct a set of ownership categories based on the identity and ownership share of the largest owner and the legal form of owner- 
ship.

Our viewpoint is that ownership matters for three reasons in particular. First, potential owners differ (with respect to goals, economic competence, information access, risk preference etc). Second, legal ownership modes differ (with respect to the bundle of rights allocated to the owner). Third, the level of ownership concentration determines the trade off between monitoring efficiency (high concentration) and diversification of risk. Ownership, therefore, has at least three dimensions: 1) identity (of the largest owner, 2) ownership concentration (share owned by the largest owner) and 3) the legal form of the company (e.g. proprietorship vs. cooperative vs. joint stock company).

The ownership categories were constructed in the following way. Information about the largest owner was found for each of the 100 largest companies in 12 European nations. On this basis a distinction was made between minority and majority ownership. Thus, minority ownership implies that the largest owner holds less than $50 \%$ of the votes. If the company turned out to be a cooperative, it was categorized as such. If the largest owner holds less than $20 \%$ of the company's votes, its ownership form was classified as dispersed regardless of the owner's identity. If the largest owner holds between 20 and $50 \%$ of the votes, its ownership was categorized as dominant, again regardless of the owner' s identity. In case of Majority ownership (defined by the largest owner holding more than $50 \%$ of the votes) the company was classified according to the identity of the majority owner, that is owned by a single person/family, by the government or by a foreign multinational. A $n$ exact definition of the ownership categories as well as the other variables employed is given in table 1. 
// Insert table 1 around here //

The ownership information was collected for the 100 largest non-financial companies in each of the following 12 European nations in 1990: Austria, Belgium, Denmark, Finland, France, Germany, Great Britain, Italy, the Netherlands, Norway, Spain and Sweden.

We also collected information about a number of standard variables: industry (63 4-digit ISIC codes), firm size and a number of nation variables.

\section{Nation effects}

Table 2 (extracted from Pedersen and Thomsen 1997) documents ownership differences among 12 European nations using the typology explained in the previous section.

// Insert Table 2 around here//

There appear to be clear differences between European nations. A chi-square test for equal distribution of ownership categories in all countries confirms the initial impression of significant differences (Pedersen and Thomsen 1997). In other words, hypothesis 1 is supported by the data. For example, dispersed ownership is common in Great Britain and 
(to a lesser extent) in the $\mathrm{N}$ etherlands, but rare or non-existent in the rest of Europe. Foreign ownership is predominant in Belgium and Spain, but is much less frequent in the rest of Europe. Government ownership is common in France and Italy, but uncommon in the Netherlands, Great Britain and Belgium. Cooperatives play a significant role in the Scandinavian economies and in the N etherlands. Dominant minority ownership (a characteristic of bank participation) is common in Germany.

But the table fails to support hypothesis 4 . The ownership structures in the largest UK companies are much more similar than in most continental nations where a greater plurality of ownership structures is generally observed. It may be that greater differentiation is observed in other sectors of the British economy.

Why do ownership structures differ so much between nations? Informal scrutiny of the table appears to support some of Whitley's basic ideas.

The role of government regulation is evident the extent of government ownership (a radical form of government intervention) in Europe in general and in particular in France, Italy and A ustria. A part from the national ization/privatization waves in F rance, post world war II nationalization played a role in Italy and A ustria. A long the same lines, openness to foreign direct investment has been a deliberate Belgian policy which may (along with geographic location advantages) have assisted the exceptional number of foreign subsidiaries in that country. 
The financial system also appears to play a role. For example, ownership structures are more dispersed in the UK and in the Netherlands which have well-developed stock markets than in (bank-based) Germany or the Scandinavian countries, where cooperatives have been an important source of finance for farm-related products. These patterns may well be related to industrialization history as hypothesized by Whitley. A familiar observation in economic history is that early industrializers like Britain and the $\mathrm{N}$ etherlands attracted funds from the share markets (with highly dispersed ownership), second movers like Germany relied more on bank finance and the government was seen as having a role in catching up among late industrializers like Italy and Spain.

However, non-institutional factors may also be important, for example geography may play a role in terms of country size as well as availability of natural resources (agriculture, natural resources). For instance, that the high frequency of cooperatives in Denmark and the Netherlands is associated with a relative specialization in agricultural industries (in which the frequency of cooperatives is generally high). Country size may also be important both in terms of market size and via an indirect effect on the size of the largest firms (which tend to be larger in large countries). H owever, there are marked differences even among large countries (Germany, France, UK) and the nation effect remains significant after controlling for country size (Pedersen and Thomsen 1997).

One final observation to be made in table 2 is the striking dissimilarity of the individual countries which seems to indicate that classification by broad categories may conceal 
important differences between national systems. We experimented with a classification of the 12 nation into some of the system categories proposed by Whitley (1994):

Partioned (group1): $\quad$ UK, NL

Collaborative (group2): Germany, Denmark, Sweden, Norway and Finland

Co-ordinated (group3): A ustria, France, Belgium, Italy, Spain

and found a significant association with the data in table 2 . However, the categorization is subject to some subjectivity bias. And our data also demonstrates major differences within these system categories which can be meaningfully related to the corporate governance literature. For example there are major differences between the markets for corporate control in the UK and the Netherlands, the banking systems in Germany and D enmark/N orway, the extent of foreign direct investment in Belgium/Spain and France. We therefore maintaine our focus on national systems of corporate governance.

\section{Testing system and economic effects}

To test the influence of system vs economic effects on European ownership structures, we would like a test of the relative importance of general economic factors (firm size, industry) and nation effects. This is clearly a multi-dimensional problem since we have 6 ownership categories (into one of which any of our 1200 companies falls) and we seek to explain the distribution over these 6 categories by firm size (one degree of freedom), industry (62 degrees of freedom, since we have 63 industries) and nation (11 degrees of freedom since we have 12 
nations in the sample). Conventional (parametric) tests of association quickly exhaust the 1200 observations available. However, if we assume a general association in the data (so that a company located in specific industry has a higher probability of belonging to a particular ownership category regardless of its nationality), we can use a Cochran-Mantel-Haenszel test of general association to detect whether significant industry effects remain after controlling for nation and size effects (table 3 ).

// Insert table 3 around here //

It turns out that both industry and nation effects have a significant association with ownership structure. The tests indicate that after controlling for size and industry there are still distinctly different patterns of ownership structures between the 12 European nations. The nation effect is significant with a probability of independence (no nation effect) of less than 0.001 , even after controlling for industry and company size.

The results also indicate that industry has a significant influence on corporate ownership (even after controlling for nation and company size). The distribution of ownership structures over industries appears to follow a non-random pattern which is generally consistent with the predictions of general ownership theory (Pedersen and Thomsen 1998). Thus, cooperatives tend to exist in farm-related businesses. Multinational companies and their subsidiaries are predominant in scale and scope intensive industries like cars, chemicals or oil, government ownership is particularly common in classical public utilities (water, electricity, telecommunication, railroads, postal services). This indicates the existence of general economic forces which are strong enough to cut across nation/system effects. 
Obviously, the existence of significant industry effects does not in itself prove the significance of economic forces. For example the apparently viable privatization of public utilities in the UK indicates that government ownership is not given by "laws of nature". And political motives appear to have been important for the creation of cooperatives in the Scandinavian countries. In an assessment of the potential impact of economic forces, we have previously examined to what extent the observed industry effect could be attributed to classical industry variables like average firm size, industry growth rates, capital intensity, risk, research intensity and profit margins (Pedersen and Thomsen 1998). All of these effects were found to be significant at the $1 \%$ level and to explain $58 \%$ of the industry effect on ownership structure.

Given industry and national origin, company size (grouped in 10 size categories) does not seem to have any direct influence on corporate ownership structures (rejecting the null hypothesis of independence runs a $10.1 \%$ risk of error). One reason is no doubt that some size effects are captured by the nation and industry effects. It is clear that the largest firms in large nations tend to be relatively large (see Scherer and Ross 1989 p. 63 for some simple calculations) and it is also clear that firm size tends to vary by industry even comparing different nations (e.g. Scherer and Ross p. 86). However, since size is a continuous measure (dollar sales) we can apply standard analysis of variance for a precise, controlled estimation of the size effect. Table 4 reports ANOVA estimates of the association between firm size (measured by turnover in US\$) and ownership structure.

// Insert table 4 around here // 
The findings are very much in accordance with expectations. Statistically speaking, there are 3 distinct size groups at the 5\% level of significance (the Duncan groups). These are A) Companies with dispersed ownership are larger than companies from other ownership categories. B) Companies with dominant minority and government ownership are smaller than companies with dispersed ownership, but larger than C) Cooperatives and companies owned either foreign multinationals, families or single individuals. Naturally, the limited size of the multinational companies is attributable to the fact that they are national subsidiaries which are compared to domestic parent companies.

Controlling for nation and industry (main) effects, the size effect remains significant even though roughly half of the observed effects may be attributable to differences among industries and nations. There is a tendency, for example, for companies with dispersed ownership to be larger than companies with dominant minority ownership, on average 2 billion US\$ larger, half of which is potentially attributable to the fact that companies with dispersed ownership tend to be more frequent in countries and industries that have many large companies. But even within the same industry and nation companies with dispersed ownership tend to be larger.

Estimating the size-effect relative to dispersed ownership one finds the same size rank order except that multinational subsidiaries now appear to be smaller than family-owned companies and cooperatives. This rank change is attributable to the fact that the frequency of multinational subsidiaries is high in nations (like Britain and Germany) and industries (like chemicals) which have quite large domestic companies. 
In conclusion hypothesis 2 (on the relative insignificance of industry effects) is rejected by the data.

\section{The origins of national corporate governance systems}

In the following we further examine to what extent the nation effect can be attributed to the institutional factors which are highlighted in Whitley's work. The importance of complementary institutions is explored in Pedersen and Thomsen (1997), where we find that a large part of the international variance in ownership structures is potentially attributable to stock market size, the size of the banking sector, the use of dual class shares and openness with regard to foreign direct investment. These findings indicate that a substantial share of the international variation in European ownership structures is attributable to government regulation and the structure of the national financial systems. In other words, they support hypothesis 3. The work of Laporta et al. (1998) also tends to support the importance of government regulation of the financial system for corporate ownership structures.

At first glance W hitley' s insistence of the importance of labour market organization is more difficult to apply to the explanation of corporate ownership structures. However, in some countries (Germany, Scandinavia) strong labour unions have been conceded seats on the boards of the largest companies which could affect the impact of ownership structure on 
company behaviour and performance (and thereby ownership structure, Furubotn and

Pejovich 1974 ). We therefore tested the impact of employee board representation on ownership structure. One hypothesis is that employee representation will limit the control benefits of large owners, which should reduce ownership concentration. A $n$ alternative hypothesis is that employee representation will stimulate the creation of countervailing power (i.e. concentration of ownership rights) to ensure that owner interests are represented by the board.

Table 5 provides a test of the explanatory power of some institutional variables in explaining the differences in international ownership structure observed in table 2 (stock market size relative to GDP, mandatory employee representation on boards, regulation of foreign direct investment).

// Table 5 //

The results confirm that these variables have a statistically significant effect. A large stock market tends to increase the frequency of dispersed ownership. This may be argued to be partly a tautology, but substituting the investor protection measure constructed by Laporta et al (1998) yields similar significant results. We have reported the stock market measure because it also captures other effects of stock market size than those attributed to the investor protection measure. Employee representation tends to work in the opposite direction (in support of the countervailing power hypothesis). Regulation (authorization requirements for FDI) tends to reduce the frequency of foreign subsidiaries. 
However, institutional variables should be tested against an alternative hypothesis. Presumably both institutional and non-institutional fores may be at work (Demsetz 1998). Table 6 therefore tests the impact of some traditional economic variables: average firm size, the size and international openness of the economy. As in previous work (Pedersen and Thomsen 1997), we hypothesize that differences in company size are likely to lower the level of ownership concentration, increase the frequency of government ownership and lower the frequency of cooperatives. The size of the economy should tend to increase the size of the stock market and thereby make it more attractive to diversity ownership. The openness of the economy should increase foreign direct investment and the frequency of foreign ownership.

\section{// Table 6 //}

To some extent, these expectations are supported by the data. As documented at the microlevel in table 4, differences in the size of the largest companies are indeed one cause of the large international variations in ownership structure. Furthermore, openness of the national economy tends to increase the frequency of foreign subsidiaries. The size the of the economy also appears to have a significant effect, but in the opposite direction of what was expected. Given that both standard economic and institutional variables appear to have a significant impact, we also test to what extent these effects are compatible by including them in the same model (table 7).

// Table 7 //

Table 7 demonstrates that both types of explanations remain significant when examined jointly. 
The effects of the institutional variables are generally weaker and the effects of regulation on the frequency of foreign subsidiaries becomes insignificant. However, a large share market is again found to increase ownership diversification (reduce family and state ownership). And the level of ownership concentration is again found to be higher in countries with employee representation on (supervisory) company boards.

Obviously these findings are subject to reverse causality problems. From one perspective a high trade intensity (a standard economic measure) represents the impact of low trade barriers (an institutional factors). However, institutions may also be endogenous, for example if small economies liberalize their trade because they have to rely trade for a substantial part of their consumption and production. Following North (1990) we believe that causality problems of this kind are to be expected given the existence of positive feedback and lock-in effects.

In conclusion, the results indicate that both economic and institutional variables influence ownership structures. In particular, hypothesis 3 is still supported after controlling for standard economic variables.

\section{Discussion}

This paper has applied ideas from Richard Whitley's analysis of business systems to study ownership structures among the largest 100 companies in 12 European countries. The results indicate that there are significant nation/system effects which can be attributed at least partly to the institutional factors highlighted in Whitley' s framework. On the other hand, we have documented the existence of significant industry effects, which indicates that general economic 
factors as well as system effects shape the governance structures of the largest European companies. Finally, we have been unable to confirm the existence of larger variation in British ownership structure than is found on the continent. Our findings therefore support the general direction of Whitley's business systems analysis along with other contributions (La Porta et al. 1996, 1997, Roe 1991, 1994, Prowse 1995). But our findings are also a tribute to the new institutional economics, since general ownership theories (hitherto based mainly on US data seem to apply to other countries as well.

As for policy conclusions, these findings indicate that governments and other actors have significant discretion in shaping the character of their corporate governance systems, but their freedom is not infinite. There are general economic forces which need to be taken into consideration and which can only be ignored at some, potentially high costs. Whitley's assertion of distinct managerial rationalities is only true with some qualifications. We believe that the recent crisis in East Asian business systems is a case in point. Writing in 1992, Whitley began his influential book with the following sentence:

"The relative decline of the United States in the wold economy since 1970 and the concomitant rise of Japanese firms in many sectors, have encouraged growing interest in the comparative analysis of business organization, as well as reinforcing doubts about the general applicability of US management theories and practices” (Whitley 1992).

Now, 6 years later, we are more reluctant to conclude that Japan and other Far Eastern countries would not have benefited from greater attention to US practices in capital budgeting, information disclosure, accountability, shareholder value and respect for basic market 
mechanisms. Nevertheless, we maintain that Whitley's insights regarding the viability of non US forms of ownership remain true regardless of the present crisis: There is generally more than one solution to the coordination of economic activity. But neither are there likely to infinitely many solutions, and to be viable institutions and systems have to pass the joint tests of technical and institutional efficiency.

As to implications for further research, Whitley and others have made important contributions by pointing to the importance of system effects on corporate governance (as well as on many other phenomena) and by highlighting the critical role of government regulation and financial systems in shaping these systems. These insights deserve to be incorporated into the economic theory of the firm. But the theory could also be refined considerably by analysing the causes of institutional differences as well as the mechanism by which they affect the economy. Why, for example, is the financial system so critical ? Why do governments tend to follow distinct paths of intervention and regulation? What are the critical policy areas which discriminate between different systems? And to what extent is company behaviour influenced by the formal institutions of governance?

\section{References}

A gresti, Alan. Categorical Data Analysis. New Y ork: John Wiley \& Sons, 1990.

Baums, Theodor, Hopt, K. J. and Buxbaum, R. (eds.). Institutional Investors and Corporate Governance. Berlin: de Gruyter, 1994.

Charkham, J onathan P. Keeping Good Company - A Study of Corporate Governance in Five Countries. Oxford: Clarendon Press, 1994.

Coase, Ronald H. "The Nature of the Firm." Economica (New series), 4 (1937), pp. 386405

Demsetz. Harold. "The Structure of Ownership and The Theory of the Firm." Journal of Law and Economics, 26 (1983), pp. 375-390.

Demsetz, Harold. "On the Contrast Between Institutional and Non-Institutional Sources of Economic Growth." Paper presented to the second annual meeting of the international 
society for the new institutional economics, Paris, September 1998.

Demsetz, Harold and Lehn, Kenneth . "The Structure of Corporate Ownership: Causes and Consequences." Journal of Political Economy, 93(1985), pp. 1155-1177.

Debreu, Gerard. The Theory of Value. An Axiomatic Analysis of Economic Equilibrium. John Wiley. New York, 1959.

Fama, Eugene F. and Michael C. Jensen. "Agency Problems and Residual Claims." Journal of Law and Economics, 26(1983), pp. 327-49.

Foss, Nicolai J. "Understanding Business Systems: An Essay on the Economics and Sociology of Organization." International Studies in Management and Organization, this issue.

Franks, Julian and Mayer, Colin. "Takeovers: Capital Markets and Corporate Control: A Study of France, Germany and the UK." Economic Policy, 14(1990),. pp. 189-231.

Franks, Julian and Mayer, Colin. "Ownership and Control." In Horst Siebert (ed.). Trends in Business Organization: Do Participation and Cooperation Increase Competitiveness? Tübingen: J.C.B. Mohr. 1995.

Fukuyama, Francis. Trust. New York: Free Press, 1995.

Furubotn, Erik And Pejovich, S. The Economics of Property Rights. Cambridge, Mass.: Ballinger, 1974.

Hansmann, Henry. 1988. "Ownership of the Firm." Journal of Law, Economics, and Organization, 4(1988), pp. 267-305.

Hansmann, Henry. The Ownership of Enterprise. Cambridge Mass.: The Belknap Press of Harvard University Press. 1996.

Hart, O. 1995. Firms, Contracts, and Financial Structures. Oxford: Oxford University Press. H ofstede, Geert. "Culture and Organizations." International Studies of M anagement and Organization 10(1980) pp.15-27.

Hoshi, Takao. "U nderstanding J apanese Corporate Governance". Paper presented at the A sia Research Centre, Department of International E conomics and M anagement, Copenhagen Business School, September 1997.

Jensen, M. and Meckling, W. "Theory of the Firm: Managerial Behaviour, Agency Costs, and Ownership Structure.” Journal of Financial Economics, 3 (1976), pp. 305-360

Laffont J.-J. and Tirole, J. . A Theory of Incentives in Regulation and Procurement. Cambridge, MA: MIT Press, 1993.

Laporta, Rafael; Lopez-de-Silanes; Shleifer, A; Vishny; R. W. 1997. "Trust in Large Organizations". American Economic Association Papers and Proceedings, American Economic Review, 87(1997) , p. 333-339.,

Laporta, Rafael; de-Silanes Lopez; Shleifer, Andrei; Vishny, Robert W. 1998a. "Law and Finance". Discussion Paper Number 1768. Harvard Institute of Economic Research. Harvard University. Cambridge, AM,. 02138. June. 1996. Journal of Political Economy, Forthcoming.

Laporta, Rafael; de-Silanes Lopez; Shleifer, Andrei. "Corporate Ownership Around the World", unpublished working paper, Second Draft, 1998b.

Moerland, Peter W. "Corporate Ownership and Control Structures: An International Comparison." Review of Industrial Organization, 10(1995), pp. 443-464

North, Douglas C. Institutions, Institutional Change and E conomic Performance.Cambridge: Cambridge U niversity Press, 1990.

Pedersen, Torben and Thomsen, Steen."European Models of Corporate Governance." Papers and proceedings. European International Business Academy Annual Meeting, 
Urbino, December 1995, pp. 315-333.

Pedersen, Torben and Thomsen, Steen. "European Patterns of Corporate Ownership: A

Twelve Country Study". J ournal of International Business Studies, 28 (1997), pp.

759-778.

Pedersen, T. and Thomsen, S. "Industry and Ownership Structure". W orking Paper, Copenhagen Business School, W P-6-1997. International Review of Law and Economics, Forthcoming, 1998.

Porter, M ichael E. Capital D isadvantage: A merica's F ailing Capital Investment System. Harvard Business Review, 70(1992), pp. 65-82.

Prentice, D. D. \& P. R. J. Holland, editors. Contemporary Issues in Corporate Governance. Oxford: Clarendon Press, 1993.

Prowse, Stephen. 1995. Corporate Governance in an International Perspective: A Survey of Corporate Control M echanisms A mong

L arge Firms in the U.S., U.K., J apan and Germany. Financial Markets, Institutions and Instruments, 4 (1995), pp.

Putterman, L ouis. "Ownership and the Nature of the Firm." J ournal of Comparative Economics, 17(1993), pp. 243-63

Roe, Mark J. A Political Theory of Corporate Finance. Columbia Law Review, 1(1991), pp. 10-67.

Roe, Mark J. "Some Differences in Corporate Governance in Germany, Japan and America." In Baums, T., T. Buxbaum \& K. J. Hopt, editors. Institutional Investors and Corporate Governance. Berlin: de Gruyter, 1994a..

Roe, Mark J. Strong Managers, Weak Owners - the Political Roots of American Corporate Finance. Princeton: Princeton University Press, 1994b.

Scherer, Frederich. M. \& Ross, David. Industrial Market Structure and Economic Performance. Boston: Houghton Mifflin, 1989.

Shepherd, William. G. Public Enterprise: Criteria and Cases. In H. W. de Jong, editor, The Structure of European Industry. Dordrecht: Kluwer A cademic Publishers, 1989.

Shleifer, A ndrei. "Government in Transition." European Economic Review, 41(1997), pp. 385-410.

Shleifer, Andrei and Vishny, Robert. W. "Large Shareholders and Corporate Control." Journal of Political Economy, 95 (1986), pp. 461-488.

Shleifer, Andrei and Vishny, Robert. W. "A Survey of Corporate Governance." Journal of Finance, 52(1997), pp. 737-783.

Whitley, Richard. Business Systems in Asia: Firms, Markets and Societies. London: Sage, 1992.

Whitley, Richard. "Dominant F orms of Organization in M arket Economies". O rganization Studies 15(1994), pp. 153-182.

Whitley, Richard. And K ristensen, P. The Changing European Firm. London.: Routledge, 1996.

Williamson, Oliver E. Markets and Hierarchies. Free Press. 1975.

Williamson, Oliver E. The Economic Institutions of Capitalism. Free Press. 1985.

Williamson, Oliver E. "Comparative E conomic Organization: The A nalysis of Discrete Structural A Iternatives." Administrative Science Quarterly, 36 (1991), pp. 269296.

Williamson, Oliver E. "Transaction Cost Economics and Organization Theory", Industrial 
and Corporate Change, 2(1993), pp. 107-156.

Williamson, Oliver E. The Mechanisms of Governance. N.Y, Oxford University Press. 1996. 
OW NE RSHIP CATE G ORY (as of 1990)

1. Dispersed ownership: No single owner owns more than $20 \%$ of the company's shares.

2. Dominant ownership: one owner (person, family, company) owns a sizeable (voting) share $(20 \%<$ share $<50 \%)$ of the company.

3. Personal/family ownership: one person or a family owns a (voting) majority of the company. We include in this category foundation (trust) ownership because it reflects the will of a personal founder and often gives the family (heirs) some degree of control.

4. G overnment ownership: the (local or national) government owns a (voting) majority of the company

5. Foreign ownership: a foreign multinational (M NE) owns a (voting) majority of the company.

6. Cooperatives: the company is registered as a cooperative or (in a few cases) majority owned by a group of cooperatives.

INDUSTRY (4-digit ISIC code. 63 industries, Europe' s Largest Companies and other sources).

FIRM SIZE..(turnover bill. US\$, average 1990-1993, Europe' s largest companies and other sources).

COUNTRY VARIABLES

Stock market relative to GDP (World Competitiveness Report 1991)

Are Employees entitled to seats on the board of Large Companies? (Buxbaum 1994 and other sources)

Authoritization required for Foreign Direct Investment? (Dummy, OECD 1992) Average Company Size by nation (turnover bill. US\$, average 1990-1993).

Size of the Economy (LOG GDP US\$1990, World Competitiveness Report 1991) )

Trade Intensity (Exports,/GDP, World Competitiveness Report 1991) 


\begin{tabular}{|c|c|c|c|c|c|c|c|}
\hline \multirow[t]{2}{*}{ Nation } & \multirow{2}{*}{$\begin{array}{l}\text { Average } \\
\text { share of } \\
\text { largest } \\
\text { owner } \\
(\%)\end{array}$} & \multicolumn{6}{|c|}{ Ownership type } \\
\hline & & $\begin{array}{l}\text { Dispersed } \\
\text { ownership }\end{array}$ & $\begin{array}{l}\text { Dominant } \\
\text { ownership }\end{array}$ & $\begin{array}{l}\text { Family } \\
\text { owned }\end{array}$ & $\begin{array}{c}\text { Foreign } \\
\text { owned }\end{array}$ & $\begin{array}{l}\text { Coopera- } \\
\text { tive }\end{array}$ & $\begin{array}{l}\text { Govern- } \\
\text { ment } \\
\text { owned }\end{array}$ \\
\hline Belgium & 76.5 & 4 & 20 & 6 & 61 & 3 & 6 \\
\hline Denmark & 67.8 & 10 & 9 & 30 & 23 & 17 & 11 \\
\hline Finland & 64.5 & 12 & 25 & 23 & 11 & 10 & 19 \\
\hline France & 54.6 & 16 & 28 & 15 & 16 & 3 & 22 \\
\hline Germany & 62.8 & 9 & 30 & 26 & 22 & 3 & 10 \\
\hline $\begin{array}{l}\text { Great } \\
\text { Britain }\end{array}$ & 30.7 & 61 & 11 & 6 & 18 & 1 & 3 \\
\hline Italy & 71.6 & 0 & 22 & 20 & 29 & 0 & 29 \\
\hline $\begin{array}{l}\text { Nether- } \\
\text { lands }\end{array}$ & 56.2 & 23 & 16 & 7 & 34 & 13 & 7 \\
\hline Norway & 75.9 & 6 & 14 & 29 & 19 & 19 & 13 \\
\hline Spain & 61.2 & 6 & 22 & 8 & 45 & 5 & 14 \\
\hline Sweden & 65.2 & 4 & 31 & 18 & 14 & 12 & 21 \\
\hline
\end{tabular}

* Cooperatives are not included in the calculation of the average ownership share. 


\begin{tabular}{l|lcc}
\hline Hypothesis & Control & variables & Probability of \\
\hline Ownership - & Size & Industryendence \\
Ownership - - Industry & Size & Nation & 0.000 \\
Ownership - - Size & Nation & Industry & 0.000 \\
& & & 0.101
\end{tabular}

Explanation: _- =association with $\mid=$ given the control variables

On average we have $1200 / 6=200$ observations per ownership category which could in principle be explained by $62 * 11=682$ nation-specific industry effects. To overcome this problem we rely on the the Cohran-M antel-H aenszel test which calculates a measure of the deviation between actual ownership patterns and what these patterns would look like if they were independent of the variables in question (the deviations are weighted by their variance). This is done for each level of the control variables and the scores are added up. The test value in the Cochran-M antel-Haenszel test is (A gresti 1990):

$$
\text { Value }=(\mathbf{n}-\mathbf{m})^{\prime} \mathbf{V}^{-1}(\mathbf{n}-\mathbf{m})
$$

where $\mathbf{n}$ is the vector of the cell counts in the frequency table for ownership mode and country on each level of company size and industry, $\mathbf{m}$ is the vector of the expected values under the condition of independence and $\mathbf{V}^{-1}(\mathbf{n}-\mathbf{m})$ is the inverse variance of the value ( $n$ $\mathrm{m}$ ). The test value follows a hyper geometrical distribution which for large $n$ approaches a chi-square distribution. L arge test values indicate large deviations from what the data would have looked like under the hypothesis of independence and lead to a rejection of the hypothesis.

The test is weak to the extent that there can be different kinds of (possibly contradictory) associations in different strata of the data, so a rejection of a significant association does not mean that no association exists (it may be that belonging to a certain industry in Spain has the opposite effect of belonging to the same industry in Britain, but that on aggregate they cancel out so that no general association exists). In contrast, significance of the $\mathrm{CM} \mathrm{H}$ test is a fairly strong indication that significant correlations exist (which are strong enough to cut across possible counter-effects in different sub-strata). 


\begin{tabular}{|c|c|c|c|c|}
\hline $\begin{array}{l}\text { OWNERSHIP } \\
\text { CATEGORY }\end{array}$ & $\begin{array}{l}\text { Av. Turnover } \\
\text { (billion US\$) }\end{array}$ & $\begin{array}{l}\text { Duncan } \\
\text { Group }\end{array}$ & $\begin{array}{c}\text { Effect relative } \\
\text { to dispersed } \\
\text { ownership }\end{array}$ & $\begin{array}{l}\text { Relative effect } \\
\text { controlling for } \\
\text { nation and } \\
\text { industry }\end{array}$ \\
\hline Dispersed & 6.1 & A & & \\
\hline Dominant & 3.9 & B & -2.2 & -1 \\
\hline Government & 3.5 & B & -2.6 & -1.4 \\
\hline $\begin{array}{l}\text { Foreign Multi- } \\
\text { national }\end{array}$ & 1.9 & $\mathrm{C}$ & -4.2 & -3.2 \\
\hline Family & 1.9 & $\mathrm{C}$ & -4.2 & -1.9 \\
\hline Cooperative & 1.1 & $\mathrm{C}$ & -5 & -2 \\
\hline
\end{tabular}


Table 5. Effect of institutional variables on ownership modes (Multinomial logistic regression).

\begin{tabular}{||l|l|l|l|}
\hline $\begin{array}{l}\text { OWNERSHIP } \\
\text { CATEGORY }\end{array}$ & Stock market size & $\begin{array}{l}\text { Employee } \\
\text { representation } \\
\text { (dummy) }\end{array}$ & $\begin{array}{l}\text { Authorization on } \\
\text { FDI (dummy) }\end{array}$ \\
\hline Dispersed & 0 & 0 & 0 \\
\hline Dominant & $-0.0614^{* * *}$ & $0.7137^{* * *}$ & 0.1151 \\
\hline Family & -799 & $1.6187^{* * *}$ & 0.3501 \\
\hline Foreign & -686 & $0.4832^{*}$ & $0.9700^{* * *}$ \\
\hline State & -919 & $0.9905^{* * *}$ & 0.1944 \\
\hline Cooperative & -491 & 1.7013 & $73.9 * * *$ \\
\hline \hline Chisquare & $146.4 * * *$ & $35.2 * * *$ & 0.03 \\
\hline
\end{tabular}

The effect on dispersed ownership function is used as a baseline

$* * *$ and $* *=$ significantly different from the effect on dispersed ownership at the $1 \%$ and $5 \%$ significance levels respectively. 
Table 6. Effect of economic variables variables on ownership modes (Multinominal logistic regression).

\begin{tabular}{||l|l|l|l|}
\hline $\begin{array}{l}\text { OWNERSHIP } \\
\text { CATEGORY }\end{array}$ & $\begin{array}{l}\text { Average Company } \\
\text { size }\end{array}$ & $\begin{array}{l}\text { Size of the economy } \\
(\log \text { GDP) }\end{array}$ & $\begin{array}{l}\text { Trade intensity } \\
\text { (Exports \% of GDP) }\end{array}$ \\
\hline Dispersed & 0 & 0 & 0 \\
\hline Dominant & $-0.9829 * * *$ & $2.4148^{* * *}$ & -0.0002 \\
\hline Family & $-0.9337 * * *$ & $1.8473^{* * *}$ & $-0.0165^{* *}$ \\
\hline Foreign & $-1.2214 * * *$ & $2.8896^{* * * *}$ & $0.0179 * * *$ \\
\hline State & $-1.1089 * * *$ & $2.4389 * * *$ & -0.0144 \\
\hline Cooperative & $-0.7715^{* * *}$ & $0.8842^{*}$ & $-0.0064 *$ \\
\hline \hline Chisqaure & $161.6457 * * *$ & $116.0547 * * *$ & $73.0579 * * *$ \\
\hline
\end{tabular}

The effect on dispersed ownership function as a baseline in calculating the interaction effect $* * *$ and $* *=$ significantly different from the effect on dispersed ownership at the $1 \%$ and $5 \%$ significance levels respectively. 
Table 7.Combined effects of institutional and economic variables on ownership modes (Multinomial logistic regression).

\begin{tabular}{||l|l|l|l|l|l|l|}
\hline \hline $\begin{array}{l}\text { OWNERSHIP } \\
\text { CATEGORY }\end{array}$ & Stock market size & $\begin{array}{l}\text { Employee } \\
\text { representation } \\
\text { (dummy) }\end{array}$ & $\begin{array}{l}\text { Authorization on } \\
\text { FDI (dumm) }\end{array}$ & $\begin{array}{l}\text { Average Com- } \\
\text { pany size }\end{array}$ & $\begin{array}{l}\text { Size of the econ- } \\
\text { omy } \\
\text { (log GDP) }\end{array}$ & $\begin{array}{l}\text { Trade intensity } \\
\text { Exports } \% \text { of } \\
\text { GDP) }\end{array}$ \\
\hline Dispersed & 0 & 0 & 0 & 0 & 0 & 0 \\
\hline Dominant & -0.0208 & $0.9812^{* * *}$ & $-0.7714 * *$ & $-0.5512^{* * *}$ & $1.6827 * * *$ \\
\hline Family & $-0.0390 * * *$ & $1.4226^{* * *}$ & -0.0949 & $-0.3856^{* *}$ & 0.7449 \\
\hline Foreign & -0.0094 & $0.8858^{* * *}$ & -0.1289 & $-0.8200^{* * *}$ & $2.0494 * * *$ \\
\hline State & $-0.0382^{* *}$ & $1.0425 * * *$ & -0.2277 & $-0.5919 * * *$ & $1.4383 * * *$ \\
\hline Cooperative & -0.0073 & $1.1570^{* * *}$ & -0.2277 & 0.4278 & $0.0302 * * *$ \\
\hline \hline Chisquare & $14.0 * *$ & $13.3 * *$ & $26.2 * * *$ & $34.7 * * *$ & 0.2462 \\
\hline
\end{tabular}

The effect on dispersed ownership function is used as a baseline

$* * *$ and $* *=$ significantly different from the effect on dispersed ownership at the $1 \%$ and $5 \%$ significance levels respectively. 
Acknowledgements

We are grateful to Poul Andersen and Nicolai Foss for helpful comments. 